\title{
COMPLEMENTARY EFFECT OF ENTREPRENEURIAL AND MARKET ORIENTATIONS ON EXPORT NEW PRODUCT SUCCESS UNDER DIFFERING LEVELS OF COMPETITIVE INTENSITY AND FINANCIAL CAPITAL
}

\author{
Nathaniel Boso, Loughborough University, United Kingdom \\ John W. Cadogan, Loughborough University, United Kingdom \\ Vick M. Story, The University of Nottingham, United Kingdom
}

\begin{abstract}
The literature implies that entrepreneurial and market orientations are market-based resources that are essential for securing business success, but the performance impacts are unclear. In the specific field of export research, there is limited information on the interactive effect of these two market-based resources on export new product performance. Accordingly, the current study investigates the joint impacts of these two resources on export new product performance under differing levels of competitive intensity and financial capital. Using a survey of 212 British exporters, the study shows that seeking complementarity between entrepreneurial-oriented and market-oriented behaviors is a useful strategy for export new product success, especially when there is a suitably high level of competitive intensity in the export market environment, and when the export unit has greater access to financial capital. Theoretical and managerial implications of the results are discussed.
\end{abstract}

References available upon request 